\title{
A checklist of fishes of eastern Terai of Nepal
}

\author{
Prakash Kumar $^{1}$, Shishir Kumar Barma ${ }^{2}$ and Bharat Raj Subba ${ }^{1^{*}}$ \\ ${ }^{1}$ Department of Zoology, Post Graduate Campus, Ttibhuvan University, Biratnagar, \\ Nepal \\ ${ }^{2}$ Department of Zoology, Lalit Narayan Mithila University, Bihar, India \\ "E-mail: subbabharat@yahoo.com
}

\begin{abstract}
An attempt has been made to survey the existing fish species of the eastern Terai of Nepal. In three months duration, fifty three fish species belonging to twenty families were recorded. The anthropogenic activities were mostly found responsible for decline of fish species in this region.
\end{abstract}

Key words: Fishes, eastern Nepal.

\section{Introduction}

Nepal is rich in water resources and fish diversity. The main sources of water of Nepal are rivers originating from Himalayas and their tributaries. In addition to rivers, there are several lakes, ponds, reservoirs, etc. which provide shelter and feeding habitats to freshwater fishes.

The initial taxonomic work of fishes of Nepal goes back towards eighteenth century when Hamilton (1822), Hickel (1843), Gumther $(1861,1868)$ and Day (1869) made expeditions to survey fish of India and its adjoining countries. They addressed the fishes of Nepal for the first time. Since then, the inception of taxonomic works on fish of Nepal took place so far the literature are concern. Still a through survey of fishes of Himalayan waters of Nepal is incomplete. Among a good numbers of contributors to taxonomical works on fishes of Nepal, the works of Shrestha (1981), Taft (1955), Talmar and Jhingran (1991), Tereshima (1984), Shrestha (2008) and Subba (1995, 1996) deserve special mention.

The authors have made an attempt to collect and identify the fishes of eastern Terai of Nepal.

\section{Study sites}

Water bodies such as rivers (Kamala, Koshi, Londhra, Keshaliya, Singhia, Babai, Ratua, Kamlamai, Biring and Mechi) and lentic water bodies such as (oxbow lakes, man made ponds, reservoirs, cannals, ditches, pools) of eastern Nepal were selected to make maximum representations of fish species.

\section{Materials and Methods}

Fishes were collected with the help of local fisherman using cast nets, scoopnet, hooks, Dhadiya etc. The collected fishes were photographed after removing water from their body surface with the help of towel and paper. After that fishes were preserved in $40 \%$ formalin for eight to ten hours then in $10 \%$ formalin. Natural colour of fish was recorded in fresh condition. The collected fishes were brought to 
laboratory of Department of Zoology, Post Graduate Campus, Biratnagar. Identification of fish was done following standard taxonomic books.

\section{Results and Discussion}

A total of 53 species of fishes belonging to twenty families were collected within three months from January to March, 2011 (Table 1). Several commonly available fish species such as Nandus nandus, Badis badis, Aplocheilus panchax, Ompok bimaculatus, Ostedsrama cotio, Puntius condonius, Puntius chola, Brachydanio rerio, Barilius barila, Sisor rhabdophorus, Chaca chacha, Tetradon culcutia etc. could not have been included in the collection. Because of habitat loss, population of most of the fish species has declined so that it is very difficult to get them. Most of the marshy lands are facing threats so their inhabitant fishes too. Along with the disappearance of wetlands, their inhabitant fish species are disappearing. Not only the habitat loss is the cause of fish species declined but human merciless activities on the aquatic diversity also have become most countable.

Table 1. A list of fish species of eastern Nepal.

\begin{tabular}{|c|c|}
\hline Family & Species \\
\hline \multirow[t]{2}{*}{ Clupeidae } & Gadusia chapra (Hamilton-Buchanan) \\
\hline & Gadusia variegate (Day) \\
\hline \multirow[t]{2}{*}{ Notopteridae } & Chitla chitla (Hamilton-Buchanan) \\
\hline & Notopterus chitla (Pallas) \\
\hline \multirow[t]{19}{*}{ Cyprinidae } & Chagunius chagunio (Hamilton-Buchanan) \\
\hline & Labeo rohita (Hamilton-Buchanan) \\
\hline & Cirrhinus reba (Hamilton-Buchanan) \\
\hline & Cirrhinus mrigala mrigala (Hamilton-Buchanan) \\
\hline & Labeo fimbriatus (Bloch) \\
\hline & Puntius sophore (Hamilton-Buchanan) \\
\hline & Puntius ticto (Hamilton-Buchanan) \\
\hline & Puntius sarana sarana (Hamilton-Buchanan) \\
\hline & Amblypharyngodon mola (Hamilton-Buchanan) \\
\hline & Amblypharyngodon microlepis (Blecker) \\
\hline & Aspidoparia jaya (Hamilton-Buchanan) \\
\hline & A. morar (Hamilton-Buchanan) \\
\hline & Barilius bendelisis (Hamilton-Buchanan) \\
\hline & B. jalkapoorei Sp.nov. \\
\hline & Salmostoma bacaila (Hamilton-Buchanan) \\
\hline & Labeo calbasu (Hamilton-Buchanan) \\
\hline & Barilius barna (Hamilton-Buchanan) \\
\hline & Garra annandalei (Hora) \\
\hline & Esomus dandricus (Hamilton-Buchanan) \\
\hline \multirow[t]{2}{*}{ Balitoridae } & Acanthocobotis botia (Hamilton-Buchanan) \\
\hline & Schistura scaturigina (McClelland) \\
\hline Cobitidae & $\begin{array}{l}\text { Lepidocephalichthys guntea (Hamilton-Buchanan) } \\
\text { Botia lohachata (Chaudhuri) }\end{array}$ \\
\hline \multirow[t]{3}{*}{ Bagridae } & Mystus tengra (Hamilton-Buchanan) \\
\hline & Mystus aor (Hamilton-Buchanan) \\
\hline & M. bleekeri (Day) \\
\hline Siluridae & Wallago attu (Schneider) \\
\hline Schilbeidae & Ailia coila (Hamilton-Buchanan) \\
\hline
\end{tabular}




\begin{tabular}{|c|c|}
\hline & $\begin{array}{l}\text { Eutropiichthys vacha (Hamilton-Buchanan) } \\
\text { Clupisoma garua (Hamilton-Buchanan) } \\
\text { Psudeutropius atherinoides Shrivastava }\end{array}$ \\
\hline Sisoridae & $\begin{array}{l}\text { Bagarius bagarius (Hamilton-Buchanan) } \\
\text { Gagata cenia (Hamilton-Buchanan) } \\
\text { Nongra viridescens (Hamilton-Buchanan) } \\
\text { Glyptothorax cavia (Hamilton-Buchanan) } \\
\text { G. trilineatus (Blyth) } \\
\text { G. pectinopterus (McClelland) } \\
\text { Nangra nangra (Hamilton-Buchanan) }\end{array}$ \\
\hline Claridae & Clarias batrachus (Linnaeus) \\
\hline Heteropneustidae & Heteropneustes fossilis (Bloch) \\
\hline Belonidae & Xenentedon cancila (Hamilton-Buchanan) \\
\hline Synbranchidae & Monopterus cuchia (Hamilton-Buchanan) \\
\hline Mastacembelidae & $\begin{array}{l}\text { Macrognathus aculeatus (Bloch \& Schneider) } \\
\text { M. pancalus (Hamilton-Buchanan) } \\
\text { Mastacembelus armatus (Lacepede) }\end{array}$ \\
\hline Ambassidae & $\begin{array}{l}\text { Chanda nama (Hamilton-Buchanan) } \\
\text { Pseudambassis ranga (Hamilton-Buchanan) }\end{array}$ \\
\hline Mugilidae & Sicamugil cascasia (Hora) \\
\hline Gobiidae & Glossogobius giuris (Hamilton-Buchanan) \\
\hline Anabantidae & Anabas testudineus (Bloch) \\
\hline Belontiidae & Colisa faciatus (Bloch \& Schneider) \\
\hline Channidae & $\begin{array}{l}\text { Channa orientalis (Bloch \& Schneider) } \\
\text { Channa punctatus (Bloch) } \\
\text { Channa striatus (Bloch) }\end{array}$ \\
\hline Cichlidae & Oreochromis mossambica (Peters) \\
\hline Ambycipitidae & Amblyceps mangois (Hamilton-Buchanan) \\
\hline
\end{tabular}

\section{References}

Day, F. 1869. The fauna of British India, including Ceylon and Burma. Fishes Vol. I and II, xvii 538p. William Division, London.

Gunther, A.G. 1861. List of the cold-blooded vertebrate collected by B.H. Hodgson, Esq., in Nepal. Proc. Zool. Soc. London, pp. 213-227.

Hamilton, F.B. 1822. An account of the fishes found in the river Ganges and its branches. Vol. 7. 405 p.

Hora, S.L. 1921. On some new or rare species of fish from the eastern Himalayas. Rec. Ind. Mus. 22: 731-744.

Shrestha, J. 1981. Fishes of Nepal. Curriculum Development Centre. Tribhuvan University, Kathmandu, Nepal.

Shrestha, T.K. 1990. Rare fishes of the Himalayan waters of Nepal. Journal of Fish Biology 37: 213-216. Supplement Academic Press, London.

Subba, B.R. \& T.K. Ghosh. 1996. A new record of the pigmy barb, Puntius phutunio (Ham.) from Nepal. Journal of Freshwater Biology, India 8(3): 159-161.

Subba, B.R. 1995. Reports on the occurrence of Hill-stream fish, Olyra longicaudata (Mc Cleland, 1942) Siluriformes, Olyridae from Kadya river of Nepal. Journal of Freshwater Biology, India 7(2): 156-157.

Talwar, P.K. \& A.G. Jhingran. 1991. Inland fishes of India and adjacent countries. Vol. I and II. Oxford and IBH Publishing Co. Pvt. Ltd.

Tereshima, A. 1984. Three new species of Cyprinoid genus Schizothora from lake Rara, North-western Nepal. Japanese Journal of Ich. 31(2): 122-135. 